\title{
Bartleby, łowca dyskursów. O pewnej formie nie-krytyki
}

\section{KEYWORDS}

Bartleby, the study, critical discourse, resistance

\begin{abstract}
Szwabowski Oskar, Bartleby, łowca dyskursów. O pewnej formie nie-krytyki [Bartleby the Discourse Hunter. On a certain form of non-critique] Kultura - Społeczeństwo - Edukacja nr 2(12) 2017, Poznań 2017, pp. 329-344, Adam Mickiewicz University Press. ISSN 2300-0422. DOI 10.14746/kse.2017.12.16.

In article I engage the Bartleby. His strategy, resistance and the relation to the dominant language are treats as a radical critique of discourse. Bartleby can show us a different style of critique that is coherence with paradigm of the study. My analyzed is located on the field on the philosophy of education and should be understood as developing of mentioned paradigm.
\end{abstract}

W artykule stawiam tezę, że Bartleby (Melville, 2009a) ${ }^{1}$ stanowi przykład radykalnej krytyki dyskursu, która nie wikła się w problem komentarza czy próbę psychoanalizy. O ile dwa ostatnie podejścia stanowią rodzaj re-produkowania, wzmacniania panowania określonego dyskursu, o tyle strategia Bartleby'ego jest rodzajem radykalnego zerwania: nie tylko doprowadza dyskurs do jałowego rzężenia, ale również do jego zamilknięcia, osunięcia się w ciszę, w śmierć władzy. Formuła "I would prefer not to" nie jest jedynie wyrazem biernej, specyficznej formy oporu - wyrazem nie tylko braku zaangażowania nawet $\mathrm{w}$ sam protest - jest to magiczna formuła, rozkładająca struktury dyskursu.

Bartleby coraz częściej przywoływany jest w refleksji nad edukacją jako postać czy przykład opozycji wobec paradygmatu uczenia się, rozwoju w ramach bioka-

${ }^{1}$ Ponieważ niektóre sensy mogą się gubić w tłumaczeniu, kiedy uznaję to za stosowne, podaję również fragment utworu w wersji oryginalnej (Melville, 2009b). 
pitalistycznego społeczeństwa, jako ktoś, kto nawiedza obecny system, otwierając i dając przykład studiowania (Lewis, 2013; 2014; Vanhoutte, 2014; D’Hoest, Lewis, 2015). Ukazanie praktyk Bartleby’ego jako krytyki dyskursu oraz ujawnienie jego stosunku do dominującego, zmonetaryzowanego języka (Reed, 2004) stanowi jednocześnie komentarz i rozwinięcie paradygmatu studiowania. W świetle przytoczonej poniżej interpretacji jasne staje się, że próby łączenia, negocjowania między nauczaniem, uczeniem się a studiowaniem są wyrazem niezrozumienia specyfiki nowego paradygmatu. W tym sensie można traktować poniższy tekst jako niebezpośrednią krytykę propozycji Dereka R. Forda (Ford, 2016).

\section{Nawiedzenie}

Pojawienie się Bartleby’ego w kancelarii rozpoczyna serię wydarzeń, gestów, które prowadzą do stopniowego rozpadu zastanej rzeczywistości. Na pierwszym poziomie opisu historia przedstawia się następująco: do zespołu pracowników zostaje przyjęty kolejny kopista, którego pracodawca ulokowuje w przestrzeni własnego biura, z jednej strony odgradzając go od siebie parawanem, z drugiej, rozsuwanymi drzwiami od innych pracowników. Początkowo Bartleby wykonuje swoją pracę pilnie, chociaż bez entuzjazmu. Pewnego dnia, kiedy pracodawca prosi go o wspólne sprawdzenie pewnych dokumentów, w odpowiedzi słyszy: „,wolałbym nie”. Od tego momentu zwrot ten pojawia się coraz częściej, staje się odpowiedzią niemal na wszystkie pytania i prośby właściciela kancelarii. Bartleby nie tylko odmawia wykonywania dodatkowych prac, ale również pracy w ogóle. Odmawia nie tylko pracy, ale również dostosowania się do poleceń pracodawcy, odpowiedzi na pytania o jego pochodzenie, aby w ostateczności odmówić udziału w życiu jako takim.

Pierwszy opis zarysowuje trzy linie, którymi mogą podążyć dalsze odczytania. Po pierwsze, sposób wyrażania oporu - to dziwne sformułowanie „I would prefer not to"2; po drugie, swoiste rozszerzanie się odmowy; po trzecie zaś niewypowie-

\footnotetext{
${ }^{2}$ Jak zauważa Sławomir Królak, polskie tłumaczenie wspomnianego sformułowania nie oddaje do końca sensu wypowiedzi. Tłumaczenie „to prefer” jako „woleć”, co narzuca pewną określoną interpretację, tymczasem to prefer to tyle co preferować lub przekładać. (Agamben 2009, s. 127, przypis tłumacza, nr 3). O braku odniesienia formuły Bartleby'ego do woli (Lewis, 2013: 47). W oryginale istotny jest dialog, w którym adwokat-pracodawca pyta się Bartleby’ego czy "woli nie", ten zaś odpowiada, że "preferuje nie":

I would prefer not to.

You will not?

I prefer not.

(Melville, 2009b: 18).
} 
dziane powyżej „zaskoczenie”, reakcja pracodawcy i współpracowników na opór Bartleby’ego. Druga lektura koncentrowałaby się więc na działaniu, a trzy linie są prowadzone jednocześnie, chociaż niekoniecznie równolegle. Tym samym druga lektura jest lekturą zwielokrotnioną, wplątaną w serię od-czytań i (re)montażu migotań, jak i negocjowania z cudzymi mapami.

Deleuze wskazuje na dziesięć wyróżnionych użyć „wolałbym nie”, które stanowią posunięcia taktyczne, rozprzestrzeniające i wzmacniające działanie odmowy:

Pierwszy przypadek ma miejsce wówczas, gdy adwokat prosi go [Bartleby’ego - wtrącenie O.S.] o porównanie i sczytanie kopii wykonanych przez dwóch kancelistów: WOLAŁBYM NIE. Drugi, gdy adwokat prosi Bartleby’ego, by przyszedł do niego sczytać własne kopie. Trzeci, gdy adwokat nakłania Bartleby’ego do sczytania kopii z nim osobiście, twarzą w twarz. Czwarty, gdy adwokat chce go wysłać na posyłki. Piąty, gdy każe mu przejść do sąsiedniego pokoju. Szósty, gdy pewnego niedzielnego poranka adwokat chce wejść do swojego biura i widzi, że Bartleby w nim śpi. Siódmy, gdy adwokat poprzestaje na zadawaniu pytań. Ósmy, gdy Bartleby przestaje kopiować, rezygnuje z wszelkiego kopiowania, a adwokat go wyrzuca. Dziewiąty, gdy adwokat podejmuje drugą próbę wyrzucenia go. Dziesiąty, gdy Bartleby zostaje usunięty z biura, siada na poręczy schodów, a wystraszony adwokat proponuje mu inne nieoczekiwane zajęcia. (Deleuze, 2016a: 116).

Wyznaczone powyżej punkty orientacyjne stanowić będą linię, którą podążę, zagłębiając się w architekturę ${ }^{3}$. Wydaje się, że najważniejsze jest rozpoczęcie całego procesu, którego logika polega nie tyle na uskokach, cięciach, przemianach, co raczej na intensyfikacji, rozprzeszczenianiu się. Istotne jest też, niewspomniane przez Deleuze’a, jedenaste użycie, które stanowi ostatnie posunięcie i które może wyjaśniać całość strategii oraz tego, co niejako można uznać za cel oporu.

Nim pojawi się pierwsze użycie, mamy opis, jak Bartleby wykonuje swoją pracę. Jest on $\mathrm{z}$ jednej strony przesadnie w nią zaangażowany, pracuje bez przerwy, pożerając dokument za dokumentem, w dzień i w nocy, bez żadnej przerwy. Z drugiej strony, wydaje się nieobecny w tej pracy, „pisał milczkiem, bez entuzjazmu, mechanicznie" (Melville, 2009a: 18). Bartleby przypomina maszynę: nie potrzebuje odpoczynku, jest w stanie funkcjonować dwadzieścia cztery godziny na dobę, zasysa materiały i rytmicznie, w odpowiednim tempie je przerabia, jednocześnie nie wykazując żadnego zaangażowania w wykonywaną pracę - w pewnym sensie treść pracy staje się nieistotna. Brak zaangażowania wiąże się z bladością ${ }^{4}$, co może

${ }^{3} \mathrm{O}$ sposobie czytania jako zagłębianiu się w architekturę i gubieniu się w niej (Benjamin, 20011). Sposób czytania jako błądzenia, powolnego przedzierania się, modyfikowania mapy, wydaje się wiązać z duchem pisania preferowanym przez Melville’a, gdzie pisanie staje się happeningiem, jest podróżą po nieznanym terenie (Bianchi, 2011).

4 „(...) he wrote on silently, palely, mechanically” (Melville, 2009b: 11). 
odnosić się do wysysania życia przez pracę, maszynę, czyniąc to, co ludzkie, martwym. Bladość, mechaniczny rytm, milczenie, właściwe maszynie, w tym przypadku budzą niepokój, nadają niezwykłości pracy Bartleby’ego pewien ponury rys, uniemożliwiający adwokatowi cieszenie się z obserwowanego zjawiska. Szybko jednak dodaje, że jest to praca nietwórcza, nie dla poetów, niejako wymagająca sama z siebie mdłego niezaangażowania, mechanicznej powtarzalności. „Jest to czynność nudna, nużąca i letargiczna (...) dla niektórych ludzi o bardziej krewkim usposobieniu byłoby to zajęcie wręcz nie do wytrzymania" (Melville, 2009a: 18). Maszynowy charakter pracy kopisty zostaje wytłumaczony przez sam maszynowy charakter kopiowania i sprawdzania dokumentów. W ramach tego tłumaczenia dziwna bladość ${ }^{5}$ Bartleby’ego, która również ujawniała się podczas wykonywania służbowych porządków, zostaje zneutralizowana, by tuż za chwilę eksplodować, zaczynając powolny, podziemny proces destrukcji.

Właściciel przekonany jest, że kiedy wypowie rozkaz-polecenie, maszyna-Bartleby zadziała jak po wciśnięciu guzika, pochłonie papier, ruszy jej rytmiczny, pełen bezdusznego zacięcia tryb. Kiedy proces produkcji nie rozpoczyna się, a Bartleby odpowiada niezgodnie z oczekiwaniami: „wolałbym nie”, ponawia, głośniej, polecenie, przekonany, że może coś niewyraźnie wypowiedział, że Bartleby go nie zrozumiał, a może jego własne władze umysłowe go oszukały, a maszyna nie tyle odmówiła posłuszeństwa, co po prostu nie została właściwie uruchomiona. „Powtórzyłem, czego sobie życzę, tonem możliwie najwyraźniejszym. Lecz nie mniej wyraziście zabrzmiała odpowiedź, taka sama jak przedtem: Wolałbym nie" (Melville, 2009a: 19).

Pierwsze wypowiedzenie „I would prefer not to” jest momentem zacięcia się maszyny-kopiującej i zainicjowaniem nowego sposobu działania, czy precyzyjniej: zacięcie się, zobrazowane powtarzaniem (się) „I would prefer not to”, wytwarzać zaczyna inne efekty. Bartleby staje się siewcą chaosu i zniszczenia (Schultz, 2011: 597-588; Deleuze, 2016a: 124-125). Na razie jednak „zniszczenie i chaos” nie ujawniają swojej pełnej mocy. To jedynie drobne drżenie, poprzedzające nadejście trzęsienia ziemi.

Zarówno wygląd samego Bartleby’ego, jak i sposób, w jaki wypowiada swoje słowa, ujawniają coś nieludzkiego: $\mathrm{z}$ jednej strony pewną niepospolitość, z drugiej - rzeczowy charakter kopisty. Pracodawca-adwokat stwierdza, że „gdyby było $\mathrm{w}$ jego zachowaniu cokolwiek pospolicie ludzkiego, bez wątpienia usunąłbym go

\footnotetext{
${ }^{5}$ Bladość Bartleby’ego pojawia się w różnych kontekstach, wiążąc go najczęściej z czymś martwym, ale też z czymś, co nie może zostać włączone w świat pracy najemnej, z pewnym wyższym stanem. W pojmowanych przez adwokata próbach zrozumienia Bartleby przez bladość będzie odsyłany do gipsowego popiersia Cycerona, muru, bycia dżentelmenem, szaleństwa czy wręcz śmierci.
} 
z mej kancelarii, i to niezbyt grzecznie. W tych okolicznościach równie dobrze mógłbym się zastanowić, czy nie wyrzucić za drzwi mojego gipsowego biustu Cycerona" (Melville, 2009a: 20).

Mechaniczny tryb zacięcia ujawnia się podczas drugiego użycia, kilka dni później, kiedy to Bartleby zostaje wezwany, aby wspólnie z innymi sprawdzić poprawność kopii stworzonych przez niego. Tym razem adwokat-pracodawca próbuje wdać się $\mathrm{w}$ dyskusję $\mathrm{z}$ nieposłusznym pracownikiem. Ten jednak na wszystkie pytania odpowiada „wolałbym nie”, tak jakby „jakaś przemożna okoliczność powodowała, że nie był w stanie odpowiedzieć inaczej, niż to uczynił" (Melville, 2009a: 21). Tak, jakby coś nad nim panowało, jakby został poddany innej władzy i dlatego nie mógł postępować zgodnie $\mathrm{z}$ racjonalnymi przesłankami podawanymi przez pracodawcę. Jednocześnie, to, co nawiedziło Bartleby’ego, dosięga też adwokata. Traci on pewność, ponownie jego władze rozumu zaczynają się chwiać, ujawnia się ich kruchość. Nie będąc pewnym, czy sprawiedliwość i rozum są po jego stronie, zwraca się po wsparcie do pozostałych pracowników.

Stają oni po stronie pracodawcy, dominującej racjonalności, chociaż ich postawa zabarwiona jest negatywną afektywnością. Agresja, na początku jedynie pojawiająca się w kąśliwych uwagach, narasta w miarę jak rozpowszechnia się działanie Bartleby’ego. Podczas kolejnych użyć „wolałbym nie” destrukcyjne działanie intensyfikuje się, tak samo jak narasta agresja, tak też i szaleństwo, obejmując obejmuje już nie tylko adwokata, ale i współpracowników.

Nawiedzenia, tak jak i odmowa Bartleby’ego, nabierają mocy. Dziwny sposób wypowiadania się przenika również do języka oficjalnego. Adwokat zauważa, że „ostatnimi czasy nabrałem dziwnego zwyczaju mimowolnego używania wyrazu «woleć» przy wszelakich, nie zawsze stosownych okazjach” (Melville, 2009a: 36). To wmykanie się, wplątywanie prefer do słownika, rozrywania oficjalnego języka, jego udziwnianie i wprowadzanie w rakowatą mutację, dotyczy nie tylko pracodawcy. Adwokat spostrzega, że również jego pracownicy, mimowolnie, bez udziału woli, tak jakby przez przypadek, używają słowa prefer. „W sposób oczywisty ześlizgnęło się z jego [Szczypcy - wtrącenie O.S.] języka bez złej woli” (Melville, 2009a: 37). Bartleby pomieszał ich języki, a może nawet umysły. Ponadto, sama obecność dziwnego kopisty przyczynia się do rozpowszechniania plotek, które mogą podważyć społeczną pozycję adwokata (Melville, 2009a: 46-47).

Pracodawca zaczyna zdawać sobie sprawę, że jego przetrwanie jako porządnego obywatela, kompetentnego adwokata jest zagrożone. Rozpoczyna się ucieczka, w której nieruchomy Bartleby nieustannie trzyma adwokata w swoich objęciach. Staje się cieniem, który nawet wygnany, jest obecny. Pomimo zamknięcia w Grobowcu, niejako zesłania go tam, skąd przybył, do wypartego, wygnanego 
aspektu rzeczywistości, adwokat pozostaje z nim w łączności czy to poprzez listy słane przez władze zakładu, czy to przez nieustające nawiedzenie, którego jeszcze nie zracjonalizował. Dokonawszy zdrady (Deleuze, 2016a: 134), adwokat pojawia się w Grobowcu, gdzie stara się pocieszyć Bartleby’ego oraz zapewnić mu lepsze warunki egzystencji. Odpowiedź byłego pracownika jest przerażająco jasna, nie można jej wytłumaczyć zaburzeniami psychicznymi: „Znam cię”, „Wiem, gdzie jestem" (Melville, 2009a: 55), by po chwili powtórzyć swoją szaloną wypowiedź: „Dziś wolę nie jeść obiadu” (...). Co powiedziawszy, oddalił się wolnym krokiem w przeciwnym kierunku, po czym stanął twarzą ku martwej ścianie" (Melville, 2009a: 57). Pogrążając się w milczeniu i w śmierci.

\section{Rozszczepienie widma}

Tak jak wspomniałem, opór Bartleby’ego jest dość dziwny: to specyficzny nie-opór, który najcześciej określany jest mianem pasywnej odmowy. Nie będę tutaj analizował całościowego charakteru strategii nie-kopisty ani wikłał się w dyskusje na ten temat. Wykracza to zdecydowanie poza ramy niniejszego artykułu. To, co mnie interesuje, odnosi się do kwestii dyskursu. Zamiast więc szukać „istoty” oporu, pokażę jego działanie.

Od początku dziwny opór Bartleby’ego podważa racjonalność pracodawcy, wprawia jego rozum w drżenie. Nie mamy do czynienia jedynie z zachwianiem funkcji poznawczych, ale z zakwestionowaniem całego porządku społecznego, w ramach którego ustanawia się dany rozum i uznaje pewne sposoby myślenia za racjonalne. Drżenie, zaburzenie, zachwianie odsyłają do braku fundamentów, do wypartej arbitralności zarówno tego, co rozumne, jak i tego, co społeczne. Wyrwa, którą tworzy wypowiedź Bartleby’ego, wprowadza adwokata w niebezpieczny stan, otwiera przed nim perspektywę niewłaściwą dla ludzi jego sfery. „Po raz pierwszy w życiu ogarnęło mnie uczucie dominującej melancholii. Nigdy przedtem nie doświadczyłem choćby odrobiny tak dotkliwego smutku" (Melville, 2009a: 31). Melancholia z jednej strony odrywa adwokata od panujących stosunków społecznych, z drugiej otwiera go na doświadczenie braterstwa - do zupełnie innych relacji, do zupełnie innej rzeczywistości. „Krążyły wokół mnie przeczucia dziwnych odkryć” (Melville, 2009a: 32). Gdyby jednak podążył drogą otwartą przez Bartleby’ego, straciłby to wszystko, co tworzy jego podmiotowość, na czym oparta jest jego wiara w siebie i w świat, poczucie własnej wartości. Obietnica jest zagrożeniem. W pewnym sensie Bartleby jest nie tylko prześwitem (Deleuze, 2016a: 138), bramą, ale również murem ujawniającym ograniczenia samego adwokata (Springer, 1965). 
Analizując momenty użycia, dostrzega się bezradność pracodawcy wobec swojego pracownika. Od początku Bartleby ma uprzywilejowaną pozycję w kancelarii. Od pierwszego nawiedzenia adwokat dostrzega jakieś podobieństwo. Nawiązuje z nim dziwną więź. Bliskość ma charakter widmowy, tak jak sam Bartleby jest czymś, co się zjawia. Na widmowość, zjawowość Bartleby’ego zwraca uwagę między innymi Naomi C. Reed, stwierdzając, że mamy do czynienia z nawiedzeniem, że Bartleby działa jak duch (Reed, 2004: 250). Jacques Derrida, analizując figurę widma, dostrzega, że jest związane z możliwością. Przychodzi ono niejako zarówno z przeszłości, jak i przyszłości, czy może raczej zaciera różnicę, nie jest wiadome jego pochodzenie. Związane z tym, co było, ale nie zaistniało, jak i z tym, co może zaistnieć, ale nie istnieje, jest ono pewnym zobowiązaniem. Jest związane z czymś, co „mogłoby nadejść lub powrócić” (Derrida, 2016: 74). To nadejście, powrót i zapowiedź zawsze podważają teraźniejszość. Widmo tym samym otwiera rzeczywistość, staje się obietnicą. Widmo składa nam wizytę, daje do myślenia i skłania do działania. Będąc wielością, rozszczepiając się na legion widm, jest jednocześnie zawsze odniesione do nawiedzonego - „widmo widzi przede wszystkim nas” (Derrida, 2016: 169). W tym kontekście adwokat zostaje nawiedzony przez siebie samego. Tym, co go straszy, co wpędza w szaleństwo, z czym musi się zmierzyć, jest on sam, a raczej to, czym mógłby, czym może być. Jakaś resztka, coś wypartego. I coś, co nie mieści się w ramach rzeczywistości.

Norman Springer wskazuje, że adwokat nie jest zimnokrwistym kapitalistą, wulgarnym, ograniczonym przedsiębiorcą, kochającym jedynie pieniądze, ale wykształconą osobą, świadomą moralnych problemów (Springer, 1965: 410). Dan McCall ukazuje, że mamy do czynienia z osobą, która jeszcze nie dostosowała się do bezdusznego kapitalizmu, o czym ma świadczyć, że wciąż płaci Bartleby’emu, pomimo że ten nie wykonuje swojej pracy (McCall, 1989).

Można uznać, że adwokat staje się bezradny wobec Bartleby'ego z powodu wewnętrznego konfliktu, rozgrywającego się w samym rdzeniu jego podmiotowości. Mielibyśmy do czynienia z walką etyk - chrześcijańskiego miłosierdzia i kapitalistycznego pragmatyzmu. Tak jakby te dwa dyskursy, zajmujące równą pozycję w podmiocie, zaczęły blokować własne działanie - nieruchomość Bartleby’ego stanowiłaby ujawnienie zamurowania samego adwokata.

Henry Krips wskazuje, że „I would prefer not to” jest wypowiedzią, która do kancelarii wprowadza rejestr właściwy salonom. Wypowiadając wspomniane zdanie, Bartleby odwołuje się do zasad innych niż rynkowe, do relacji innych niż te oparte na pieniądzu. Działania Bartleby'ego są więc tolerowane, ponieważ podejmuje on aktywność w pełni odpowiednią w towarzystwie dżentelmenów (Krips, 
2012: 311). Jednocześnie w tym odwołaniu zawarta jest pewna przesada, teatralna sztuczność, dziwaczność uniemożliwiająca nie tylko reakcję w ramach kapitalistycznych relacji, ale również dżentelmeńskich. „Bartleby jest dżentelmenem na trupi sposób" (Reed, 2004: 250). Wykrzywia oba porządki, obnaża oba dyskursy. Podczas lektury można dostrzec, że adwokat odwołuje się do obu rejestrów, za każdym razem ponosząc klęskę. Nie-kopista nie tyle umożliwia wybór między dwoma etykami, dwiema wizjami świata, stawiając podmiot w konflikcie między rywalizującymi systemami wartości, co raczej wskazuje ich komplementarność i pustkę. Pustkę władzy i kruchość upodmiotowienia - ograniczenia danego upodmiotowienia.

Adwokat prezentuje siebie jako osobę solidną, spokojną, miłosierną, jest dobrym chrześcijaninem i dobrym przedsiębiorcą. Jest kimś poważnym, godnym poważania - jak monety. Jest twardą walutą, którą potwierdza nie tylko rynek, ale i tradycja. Jest on osobą w pełni zintegrowaną z panującym porządkiem, odnoszącą sukcesy, pełną optymizmu. Jak zauważa Springer, adwokat jest przekonany o swoim rozeznaniu w świecie i że potrafi sobie w nim radzić. Zna wartość pracy i jest za nią nagradzany nie tylko pieniędzmi, ale również pozycją społeczną. Bartleby ukazuje, że ograniczenie takiej podmiotowości jest murem dla adwokata. Wyczuwa on w nie-kopiście coś, co wykracza poza granice jego świata, jego rozumienie, odczuwa obcość i inność, której nie jest w stanie zrozumieć (Springer, 1965). Bartleby nie tylko sprawia, że adwokat ucieka w własnego biura, ale nie idzie też w niedzielę do kościoła. Rozkłada jego definicję rzeczywistości, człowieczeństwa, wymyka się wszelkim ulokowaniom, kierując wzrok ku murowi. Całkiem możliwe, że bezradność nie bierze się z bliskości, ale z obcości, z niemożliwości oswojenia, podporządkowania, wtłoczenia w ramy. Bartleby przecież nie działa tak, jak powinien. Jego odpowiedzi nie są zgodne z regułami. Nie-kopista wykoślawia język, prowadzi do jego granic, wydrąża go z wszelkiego sensu, kierując w stronę milczenia. Adwokat może jedynie neutralizować dane działanie, ratować język, możliwość wypowiadania, które wydaje mu się sensowne, traktując quasi-wypowiedzi Bartleby’ego jako przejaw szaleństwa.

\section{Obłąkane widmo}

W opowieści adwokata Bartleby odnoszony jest do szaleństwa wielokrotnie. Wytłumaczenie jego zachowań znajduje się jedynie w rejestrze choroby psychicznej. Rozkład dyskursów, milczenie, mają stanowić przejaw zaburzenia upodmiotowienia. 
Bartleby, zdefiniowany jako typ melancholijny, zajmuje określoną pozycję wobec języka. Język choremu jawi się jako coś obcego. Milknięcie jest efektem choroby. Andrew Solomon w swojej opowieści o zmaganiu z depresją pisze:

Kiedy zostaje przekroczona bezpieczna granica, zmieniają się reguły gry. To, co napisano w ojczystym języku, teraz jest chińszczyzną (...) Niewiele mówiłem. Słowa, z którymi zawsze pozostawałem w zażyłej znajomości, nagle stawały się ogromnie wymyślnymi, trudnymi metaforami. Nie znajdowałem w sobie dość energii, żeby z nich skorzystać. (Solomon, 2004: 49, 53)

To, co Solomon obserwuje na własnym przypadku, jest dla Julii Kristevej jednym $z$ istotnych przejawów choroby, uniemożliwiających egzystencję. Podana przez nią charakterystyka mowy melancholijnej może równie dobrze odnieść się do sposobu mówienia Bartleby’ego. „Jego mowa zdaje się od samego początku wymijającą, niepewna, lakoniczna, niby milcząca: mówi «się» z przekonaniem, że mowa ta jest fałszywa, a więc mówi «się» niedbale, mówi «się», wcale w to nie wierząc” (Kristeva, 2007: 48). Nieufność wobec języka stanowi niemożność podporządkowania się temu, co symboliczne, prawu Ojca. Zbyt przywiązany do własnego, niewypowiedzianego wnętrza, nie może wejść w to, co obiektywne (Kristeva, 2007: 18), zintegrować się z porządkiem, a tym samym wejść w sferę komunikacji i produkcji. Dopiero dzięki matkobójstwu staje się podmiotem i członkiem uniwersalnej społeczności, wprowadzonym w ojcowską tradycję i kojące działanie prawa. Melancholik, wierny jakieś utopii, nie potrafi przejść w logikę ekwiwalencji, stając się w pewnym sensie absolutystą, wybiera śmierć zamiast kompromisu.

W powyższym duchu odczytuje Bartleby'ego Leo Marx. Proponuje on traktować całą historię jako metaforę sytuacji pisarza w kapitalistycznym społeczeństwie, zaś nie-kopista miałby być alter ego Melvilla. Wspomniany już wcześniej kilka razy mur, który oddziela pracowników od pracodawców, który tkwi za oknem, zasłaniając wszelki widok, mur, w cieniu którego Bartleby w końcu zatapia się w milczenie i śmierć, ten mur staje się istotną metaforą. Marx zauważa, że Bartleby bliski jest traktowaniu pisania jako twórczości, jego odmowa dotyczy uznanych społecznie form pisania, traktowania pisania jako po prostu formy pracy. Odmówienie sprawdzania tekstu to odmówienie podporządkowania się społecznym relacjom, powszechnemu użyciu tekstu (Marx, 1953: 609). Zacięcie się maszyny-kopiującej zostaje odniesione do muru. Nieustanie wzrok Bartleby'ego będzie się ku niej kierował. Niemal jako dopełnienie słów „I would prefer not to”. Nie-kopista zostaje niemal opanowany przez mur, to w jego cieniu nie może pisać. Koncentracja na murze jest związana ze świadomością ograniczeń, jakim zostaje poddane pisanie i pisarz w kapitalistycznym społeczeństwie. Niemniej Marx interpretuje los Bartleby’ego jako los kogoś, kto, nie potrafiąc się pogodzić z warunkami, zostaje 
zniszczony przez koncentrację na granicach. Mur niszczy człowieka, który obsesyjnie go bada (Marx, 1953: 622). Błąd Bartleby'ego tkwi w tym, że, wpatrując się w mur, oddzielił się od ludzkości, wszystko jawi się jako sztuczne na Wall Street dlatego ginie, tak jak ginie pisarz bez publiczności (Marx, 1953: 626-627).

Zgodnie z powyższą logiką nie-kopista jest nie tyle prześwitem, nie tyle widmem, które wyłamuje rzeczywistość z zawiasów, ukazując inne sposoby istnienia, co kimś, kto po prostu nie potrafi się dostosować, kimś, kto nie potrafi negocjować z tym, co społeczne. Jego zagrożenie dla danego porządku jest zagrożeniem dla istnienia jako takiego, a adwokat-terapeuta jest tym, który może wskazać nam drogę, kimś, kto próbuje ocalić Bartleby’ego - niestety bez powodzenia.

Taka interpretacja jednak nie uwzględnia tego, co naprawdę wywrotowe. Nie tyle pokazuje Bartleby’ego jako radykalnego krytyka dyskursu, który ma własną metodę, co wzmacnia dominujące dyskursy - umieszczając wreszcie nie-kopistę $\mathrm{w}$ istniejącej strukturze społecznej, na oficjalnych marginesach, w więzieniu, jako szalonego, włóczęgę.

\section{Widoki władzy}

Bartleby nie opowiada swojej historii. Tym, kto przedstawia jego losy, zarysowuje sylwetkę i stara się nam pomóc zrozumieć tego najdziwniejszego ze skrybów, jest prawnik, szef kopisty. Oczy stają się źródłem poznania:

Nie wiem o Bartlebym nic ponad to, co ujrzałem na własne zdumione oczy, kiedy miałem z nim osobiście do czynienia, oraz nie licząc jednej niejasnej relacji, która pojawi się w dalszym ciągu tej opowieści. (Melville, 2009a: 7) ${ }^{6}$

To, co „jego zdziwione oczy zobaczyły”, „to wszystko, co wie o nim”. Odwołanie się do wzroku, że „to wszystko” się zobaczyło, z jednej strony można potraktować jako gwarancje rzetelności narratora, nie dodaje niczego, czego moje oczy nie zobaczyły, czego sam nie byłem światkiem, żadnych domysłów, żadnych plotek. Wpisywałby się tym samym w kartezjańsko-oświeceniową tradycję uprzywilewującą zmysł wzroku (Swoboda, 2010: 12). Z drugiej może wskazywać na subiektywność, na niedostępność Bartleby’ego. No był taki w moich oczach, on się mi takim jawił, tak mi się prezentował. I to nie prezentował się jako ogólnie przedmiot spojrzenia, ale przedmiot spojrzenia konkretnych - „my own” - oczu. Jedynie raz przywołuje

${ }^{6}$ „What my own astonished eyes saw, that is all I know of him, except, indeed, one vague report, which will appear in the sequel" (Melville, 2009b: 2). 
„niejasną relację, już po tym, jak Bartleby osuwa się w nicość, by w radykalnej odmowie usunąć się z władzy spojrzenia. Dopiero wtedy, gdy umiera, pojawia się (appear) doniesienie, po to, aby znowu uczynić Bartleby’ego widzialnym. Relacja, niejasna, niemal widmowa, czyni kopistę znowu widocznym, jawiącym się, widmowym znakiem, już bez podmiotu, odniesienia do istnienia, a jedynie do resztek, które cyrkulują po śmierci (Reed, 2004: 264). Nawet kiedy oczy nie dostrzegają postaci, to słowa o Bartleby się jawią.

Jedna i druga strona, obiektywność spojrzenia i subiektywność partykularnych oczu, łączą się: uprzywilejowany zmysł pokrywa się z uprzywilejowaną perspektywą patrzącego. Prawnik ucieleśnia spojrzenie władzy ustanawiającej obiektywność kapitalistycznego porządku społecznego. Jest jego wyrazicielem i granice jego światopoglądu, jego spojrzenia, są granicami społeczeństwa kapitalistycznego.

To, że Bartleby jawi się nam przez pryzmat oczu pracodawcy, jest istotne. Narrator stwierdza, że musi z tego powodu opowiedzieć o sobie, „Ludziach, których zatrudniam, moim zajęciu, mojej kancelarii oraz otoczeniu, ponieważ wszystko to jest niezbędne, by właściwie zrozumieć najważniejsza postać, którą pragnę przedstawić” (Melville, 2009a: 8). Postać prawnika jako tego, który widzi, czy raczej, komu się jawi Bartleby, jest istotna z kilku powodów, co zresztą już wspominałem - jego zadomowienie, konserwatywna natura, połączenie rejestrów, etyk, to wszystko sprawia, że dziwny kopista i jego strategia jest tak, a nie inaczej interpretowana. Równie istotne, czy też spajające etyki i rejestry, działając niczym soczewka, jest rynkowe ulokowanie adwokata: jest on pracodawcą.

Już w pierwszych słowach można dostrzec, że narrator używa języka, który wskazuje na posiadanie: „my employés, my business, my chambers” (Melville, 2009b: 2). Określa się w pozycji nadrzędnej względem pracowników, którzy są jego i, niczym niewolnicy, określają jego osobę. Nie byłby sobą, gdyby tego wszystkiego nie posiadał. To posiadające spojrzenie traktuje pracowników jako maszyny, zasób, co ujawnia się w ich opisie, gdzie poszczególne cechy odnoszone są do zdolności wykonywania pracy i pożytku, jaki przynoszą kancelarii. Jak zauważa Schultz, to pracodawca widzi Bartleby’ego jako rzecz, jako narzędzie, jako coś bez niezależnej myśli, co wcale nie oznacza, że dziwny kopista jest tym, za kogo pracowdawca go uznaje (Schultz, 2011: 592). Można przypuszczać wręcz odwrotnie.

W przeciwieństwie do Marxa uważam, że to nie Bartleby nie jest świadomy społecznej konstrukcji muru, tego, że ograniczenia zostały stworzone przez ludzi i tym samym możliwe jest życie po ich zniszczeniu, ale to adwokat widzi mur jako coś metafizycznego, związanego z samą naturą odwiecznej rzeczywistości. Dla adwokata ograniczenia są czymś danym, dlatego ich zniesienie może otworzyć tylko na otchłań, na szaleństwo, które przeczuwa w Bartlebym. Przyjmując interpretacje 
daną przez pracodawcę-narratora, musimy przyjąć perspektywę władzy, zaczynamy myśleć w ramach dominującego dyskursu, i potraktować milczenie nie-kopisty, jego strategię, jako osuwanie się w śmierć, jako po prostu odmowę życia.

Deleuze wskazuje, że psychoanaliza nie jest w stanie ująć dziecięcych map, zrozumieć „inny język”, ale narzuca klisze, odcina kłącza, dostosowuje do oficjalnych sposobów mówienia, wiąże lewą rękę za plecami. „Muszą usunąć swoje mapy, pod którymi są już tylko pożółkłe zdjęcia ojca-matki” (Deleuze, 2016b: 105). Psychoanaliza staje po stronie władzy, jest strategią adwokata - „«kuracja» ma ulżyć nie tylko Bartleby'emu, ale w takim samym, jeżeli nie większym, stopniu jego toczeniu, uosobionym przez narratora" (Paryż, 2002: 227). W tym kontekście należałoby również odczytywać Kristevej charakterystykę stosunku do języka właściwej melancholikom.

Bartleby zostaje ulokowany w konkretnych stosunkach społecznych - wie, gdzie jest. I to w ich ramach podejmuje swoją terrorystyczną akcję. Mur, ograniczenia, dominujący dyskurs są historycznymi pofałdowaniami, ustanowionymi strukturami. I w tych to konkretnych ramach należy ujmować odmowę Bartleby'ego. Wycofuje się nie ze świata, ale z tego tu świata, nie z języka jako takiego, ale $\mathrm{z}$ tak sformatowanego języka, nie z pisania jako takiego, ale $\mathrm{z}$ takich form i wymogów pisania.

Uniwersum języka, w którym znajduje się Bartleby i które odrzuca, to język rozkazu, język zarządzania, podporządkowywania hierarchicznym strukturom, rynkowym relacjom. To świat totalnego przedsiębiorstwa i zakładów odosobnienia. Język służy w tym kontekście podporządkowaniu, jest językiem wyalienowanym, w którym wszelka komunikacja jest jedynie pozorem (Pospiszyl, 2016: 111). I tak, Bartleby zrywa z językiem redukowanym do wspierania kapitalistycznego sposobu produkcji i okaleczania życia, $\mathrm{z}$ dyskursami dominacji. Toteż milczenie wskazuje na niechęć do asymilacji z tym językiem, językiem ojców, dominacji, pozoru komunikacji, z panującymi strukturami, do których odwraca się w imię życia. Jest milczeniem, o ile ujawnia cichość gadaniny; jest szaleństwem, o ile ujawnia paranoje władzy; jest murem, o ile ujawnia otaczające nas ściany...

\section{Nadmiar niczego}

Należy zauważyć, że linie styku są jednocześnie liniami odbicia. Próba wyjaśnienia Bartleby’ego w ramach tego czy innego dyskursu kończy się porażką. Bartleby jest już gdzie indziej. Jest pracownikiem, nie będąc pracownikiem, jest człowiekiem, nie będąc człowiekiem, jest obcy, będąc jednocześnie kimś najbliższym. „Tam jest 
zawsze coś więcej w Bartleby'm, coś ekstra, coś, co przekracza «tę» czy «tamtą» tematyzację" (Beverungen, Dunne, 2007: 173).

Samo istnienie Bartleby’ego jest już krytyką. Stawia on opór ojcowskiemu pragnieniu kontroli języka czy kontroli jako takiej. Schultz stwierdza, że Bartleby myśli i działa poza sposobami, obszarem wyznaczonym przez szefa (Schultz, 2011: 593). Tym działaniem poza, swoją nieuchwytnością, ujawnia kruchość podporządkowania, niepewność każdej władzy, niemożliwość totalnego zapanowania dyskursu. „Bartelby jest dokładnie tym momentem, w którym maszyna zarządzająca zawodzi, ulegając asymilacji z tym, co jej się opiera” (Beverungen, Dunne, 2007: 178). O ile sam Bartleby wycofuje się z dominującej logiki, to ta, próbując nad nim zapanować, zaczyna ulegać transformacji, dociera do swojej granicy, ujawniającej prawdę o podporządkowaniu, jego czysty imperatyw „bądź posłuszny” (Krips, 2012: 314) i tkwiącej pod każdym porządkiem arbitralnej przemocy.

Praktyka Bartleby’ego, jego kontemplacja, czy może studiowanie muru, jest czymś, co można powiązać z myśleniem jako krytyką dyskursu. Deleuze zauważa, że myślenie pochodzi z zewnętrza, rozsadzając to, co uformowane i funkcjonujące (oraz funkcjonalne) w ramach „skamielin” diagramów władzy. Zewnętrzność myślenia, będąca przestrzenią oporu, nie redukuje się do reprodukowania dominującego dyskursu. Praca oporu, jako czegoś nie tyle będącego efektem władzy, ale będącego czymś pierwotniejszym od uformowania, jest pracą sabotowania, wprowadza w drżenie, zakłóca rytmiczną pracę machiny dyskursywnej, aż do wprowadzenia jej na jałowy bieg. Zamiast więc usprawniania dyskursu, jego ulepszania, dostrzec możemy praktyki rozkładu, konstruowania i uruchamiania nowych, innych maszyn. Myślenie Bartleby’ego, jako forma myślenia krytycznego, jest pewną formą praktyki, jako przejście do jednej mapy do drugiej. Przemiany przestrzeni, przemiany dyskursu to również przemiany podmiotowości (Deleuze, 2004).

Nicość, z którą utożsamiony jest Bartleby, jest granicą władzy, granicą dyskursu, przejściem do innego porządku. Ten porządek nie jest czymś określonym, ale raczej czystą potencjalnością (Agamben, 2009; Lewis, 2013; 2014) - otchłanią życia poza słowem władzy.

\section{Śmierć dyskursu}

Strategia krytyczna Bartleby'ego nie polega na analizie dyskursu w rozumieniu rozkładania go na czynniki, podejmowania się podejrzliwej anatomii. Zamiast tego proponuje nam podwójny gest. $Z$ jednej strony jest to gest parodii, demaskacji polegającej na wykrzywianiu, teatralizacji - Bartleby wypowiada się tak, że plącze 
rejestry, wprowadza je w drżenie. Z drugiej strony jest to gest odcięcia, zerwania komunikacji, odmowa uczestniczenia w danym dyskursie, akceptacja jego zasad. O ile pierwszy wymiar gestu zdaje się lokować wewnątrz dyskursu, stanowić jego mutację, niejako akceptującą jego logikę, co najwyżej ją reformując, to już drugi ukazuje takie przeświadczenia jako złudzenie, iluzję tego, co dominuje. Może nawet należałoby powiedzieć, że gest Bartleby’ego jest po prostu gestem zerwania, zaś wszelkie wykrzywienia, mutacje, są działaniami dominującego dyskursu pragnącego przywrócić sobie totalne panowanie. Wchłonięcia Bartleby’ego w swoją logikę, ulokowania go w porządku, chociażby jako wykluczonego. Tymczasem jego krytyka polega na byciu niezintegrowanym, na radykalnej odmowie. Polega ona na nieużywaniu danego dyskursu. To, co adwokat bierze za dialog, komunikację, jest jedynie iluzją. Bartleby jedynie powtarza to, co wypowiada na samym końcu: „Znam cię i nie chcę do ciebie mówić". Nie chcieć mówić do, to niezgoda na mówieniu $w$.

- Zechcesz mi powiedzieć, Bartleby, gdzieś się urodził?

- Wolałbym nie.

- Zechcesz mi powiedzieć cokolwiek o sobie?

- Wolałbym nie.

- Lecz jaką możesz mieć racjonalną obiekcję, by ze mną porozmawiać? Jestem do ciebie nastawiony przyjaźnie.

Nie patrzył na mnie, kiedy mówiłem, wzrok utkwił w biuście Cycerona, który, gdym usiadł, miałem dokładnie za sobą, jakieś sześć cali nad głową.

- I co odpowiesz, Bartleby? - zapytałem, odczekawszy spory kawałek czasu, podczas kiedy wyraz jego twarzy nie zmienił się ani odrobinę, może z wyjątkiem ledwie dostrzegalnego drżenia jego zbielałych ust.

- W tym momencie wolę nie udzielać odpowiedzi - rzekł i wycofał się do swojej pustelni. (Melville, 2009a: 35)

O ile analiza, krytyka, nie tylko przyczyniają się do rozpowszechniania dyskursu i nieustannie negocjują znaczenia na terenie wyznaczonym przez to, co dominuje, zaś parodia stara się zawłaszczyć sposoby mówienia, dokonać ich mutacji, pracując wewnątrz jako transformowanie, to radykalna odmowa uśmierca dyskurs, odsyła go w zapomnienie, przestaje używać. Nie tyle Bartleby zatapia się w śmierci, co jest śmiercią adwokata - reprezentowanych przez niego relacji, praw i sposobów mówienia.

Z punktu widzenia władzy strategia Bartleby’ego jest szaleństwem, kresem mowy, śmiercią. Jest czymś, co nie może zostać zrozumiane. Jest jednocześnie tym nadmiarem życia, niestłumioną, niewtłoczoną w kapitalistyczną cyrkulację, mocą samego życia. Jest tym, co poprzez samo swoje istnienie wskazuje na możliwo- 
ści, będące czymś więcej niż jedynie rozwojem w ramach dominujących struktur. Strategię Bartleby’ego można zaobserwować w praktykach najnowszych ruchów społecznych czy w anarchistycznych odmianach syndykalizmu. Wydaje mi się, że ten trop jest bardzo istotny dla zrozumienia specyfiki krytyki dyskursu proponowanej w tym artykule. Mówiąc krótko, krytyka ma charakter praktyczny, związany z budowaniem odmiennych relacji społecznych, związaną z mocą bytu przeciwko sile dominujących struktur. Nie podziela iluzji, że w instytucjach funkcjonujących i wspierających dominujący dyskurs jest się w stanie wynegocjować inne sposoby życia i użycia. Opuszcza fabryki (edukacyjne) by tworzyć nomadyczne maszyny edukacyjne, pirackie sieci - umierać dla tego świata i rodzić się dla innego. Robiąc prześwity, które mogą uwodzić również w tym, co dominuje.

\section{Literatura}

Agamben G. (2009). Bartleby, czyli o przypadkowości. Tłum. S. Królak. [W:] H. Melville. Kopista Bartleby. Historia $z$ Wall Street. Tłum. A. Szostakiewicz. Warszawa.

Benjamin W. (2011). Ulica jednokierunkowa. Tłum. B. Baran. Warszawa.

Beverungen A. Dunne S. (2007) "I'd Prefer Not To”. Bartleby and the excesses of interpretation.

"Culture and Organization" 13(2), s. 173.

Bianchi R. (2011). Melville's process: Writing as performing. "Leviathan” $\mathrm{nr}$ 13(3).

D’Hoest F., Lewis T.E. (2015). Exhausting the fatigue university: in search of a biopolitics of research. "Ethics and Education" nr 10(1).

Deleuze G. (2004). Foucault. Tłum. M. Gusin. Wrocław.

Deleuze G. (2016a). Bartelby, czyli formuła. [W:] G. Deleuze. Krytyka i klinika. Tłum. B. Banasiak, P. Pieniążek. Łódź.

Deleuze G. (2016b). Co mówia dzieci. [W:] G. Deleuze, Krytyka i klinika. Tłum. B. Banasiak, P. Pieniążek. Łódź.

Derrida J. (2016). Widma Marksa. Stan długu, praca żałoby i nowa Międzynarodówka. Tłum. T. Załuski. Warszawa.

Ford D.R. (2016). Teaching, learning, and studying in the Baltimore Rebellion. "Policy Futures in Education" nr 14(2).

Krips H. (2012). Politics of overconformity: Bartleby meets Žižek. "Communication and Critical/Cultural Studies" nr 9(3).

Kristeva J. (2007). Czarne słońce. Melancholia i żałoba. Tłum. M.P. Markowski, R. Ryziński. Kraków. Lewis T.E. (2013). On Study. Giorgio Agamben and Educational Potentiality. London, New York.

Lewis T.E. (2014). It's a profane life: Giorgio Agamben on the freedom of im-potentality in education. "Educational Philosophy and Theory" nr 46(4).

Marx L. (1953). Meiville's Parable of the Walls. „The Sewanee Review” nr 61 (4).

McCall D. (1989). The Silence of Bartleby. Ithaca.

Melville H. (2009a). Kopista Bartleby. Historia $z$ Wall Street. Tłum. A. Szostakiewicz. Warszawa.

Melville H. (2009b). Bartleby, The Scrivener: A Story of Wall Street. Lexington. 
Paryż M. (2002). Iluzje dyskursu: narrator jako "psychiatra" w wybranych utworach Hermana Melville'a, Nathaniela Hawthorne’a i Edgarda Allana Poego. [W:] G. Gazda, A. Izdebska, J. Płuciennik (red.). Wokół gotycyzmów. Wyobraźnia, groza, okrucieństwo. Kraków.

Pospiszyl M. (2016). Zatrzymać historię. Walter Benjamin i mniejszościowy materializm. Warszawa.

Reed N.C. (2004), The Specter of Wall Street: „Bartleby, the Scrivener” and the language of commodities. "American Literature" nr 76(2).

Schultz R.T. (2011). White guys who prefer not to: from passive resistance („Bartleby”) to terrorist acts (fight club). "The Journal of Popular Cultura” 44(3).

Solomon A. (2004). Anatomia depresji. Demon w środku dnia. Tłum. J. Bartosik. Poznań.

Springer N. (1965). Bartleby and the terror of limitation. "PLMA" nr 80(4).

Swoboda T. (2010). Historie oka. Gdańsk.

Vanhoutte K.K.P. (2014). Bartleby the example and Eros the idea of the work: some consideration on Giorgio Agamben's "The idea of study". "Educational Philosophy and Theory" nr 46(4)/2014. 